\title{
Effects of food deprivation on the larvae of two flatfishes
}

\author{
D. M. Gadomski ${ }^{1}$, J. H. Petersen ${ }^{2}$ \\ ${ }^{1}$ VANTUNA Research Group, Occidental College, 1600 Campus Rd., Los Angeles, California 90041, USA \\ ${ }^{2}$ Section of Ichthyology, Natural History Museum of Los Angeles County, 900 Exposition Blvd., Los Angeles, California 90007 , \\ USA
}

\begin{abstract}
For greatest survival, first-feeding halibut Paralichthys californicus and diamond turbot Hypsopsetta guttulata required food by the day of total yolk absorption. Some halibut larvae survived if fed 1 or $2 \mathrm{~d}$ after yolk depletion, but their growth rate was significantly less than larvae fed earlier. Survival of 3-wk-old larvae was greater in treatments with shorter starvation periods. A small percentage of 3-wk-old halibut larvae recovered from a maximum starvation period of $4 \mathrm{~d}$ while 3 -wk-old diamond turbot successfully resumed feeding any time during food deprivation intervals lasting up to $9 \mathrm{~d}$. Longer periods of starvation resulted in significant morphological differences - diamond turbot starved longer were not only smaller, but also less developed. In the field, larvae may experience varying periods of food deprivation due to differing spatial and temporal prey patch distributions. Our results demonstrate that differences in starvation resistance, and possibly mortality under patchy feeding conditions, are ontogenetic and species-specific.
\end{abstract}

\section{INTRODUCTION}

During food deprivation, larvae of many fish species reach a stage of physical deterioration where they are still active but cannot recover even if food is available. This stage is often referred to as 'irreversible starvation' or the 'point-of-no-return' (Blaxter \& Hempel 1963, May 1974, O'Connell 1976, Theilacker 1978). The length of time until irreversible starvation occurs is dependent upon temperature, larval age and size, and fish species (Blaxter \& Ehrlich 1974, Houde 1974, Buckley 1982, Bagarinao 1986). McGurk (1984) summarized experimental data on age of irreversible starvation for yolk-sac larvae of 25 marine fishes. For first-feeding larvae, resistance to food deprivation is proportional to the amount of energy reserves available. Measured from the point of yolk absorption, time to irreversible starvation ranged from 0.5 to $9 \mathrm{~d}$ with a mean of $3.2 \mathrm{~d}$; these values were positively correlated with the time from hatching to yolk depletion and negatively correlated with temperature.

It has been hypothesized that a major cause of larval fish mortality in the field is starvation during periods of poor feeding conditions (Hunter 1976b). Eggs spawned during seasons of low plankton production or in patches of water with low food densities have little chance of survival as larvae; thus the spawning of many species coincides spatially and temporally with seasonal zooplankton peaks (Cushing 1975, Townsend 1983, Sherman et al. 1984). Other species distribute their spawning effort through a long period or over a large geographic range, ensuring that some newly hatched larvae will be present during favorable, although unpredictable, conditions. For older larvae, the immediate presence of a favorable feeding environment is not as critical, since they can resist longer periods of starvation (Blaxter \& Ehrlich 1974, Hunter 1976a). Older larvae also have increased mobility and better sensory abilities for finding prey patches (Hunter 1972, Houde \& Schekter 1981).

Our objectives were to compare the time to irreversible starvation for yolk-sac and older larvae of 2 flatfishes commonly found in coastal waters of southern California (California halibut Paralichthys californicus: Bothidae; diamond turbot Hypsopsetta guttulata: Pleuronectidae) and to relate starvation differences to field larval abundance patterns. Eggs and larvae of these 2 flatfishes are similar in size and developmental rate (eggs of both species are about $0.8 \mathrm{~mm}$ in diameter; newly hatched larvae are 1.5 to $2.0 \mathrm{~mm}$ in length; and larvae settle at $16^{\circ} \mathrm{C}$ in about 5 to $6 \mathrm{wk}$ at 7 to $8 \mathrm{~mm}$ ). There are interspecific seasonal abundance 
differences, however; halibut larvae are most common during late winter through spring (Lavenberg et al. 1986), whereas diamond turbot are abundant in late fall and early winter (Natural History Museum of Los Angeles County unpubl.). This study aims to improve understanding of how seasonal variations in prey abundances and general patchy food distributions may affect larval survival of these 2 species.

\section{METHODS}

Egg and larval supply. Fertilized halibut eggs were collected from naturally spawning brood stock held in a large (5 m diameter) outdoor tank. Ripe female diamond turbot were collected offshore and their eggs stripped and fertilized with sperm from brood stock males at the laboratory. Older larvae for experiments were reared at ambient temperatures $\left(16\right.$ to $\left.17^{\circ} \mathrm{C}\right)$ and fed rotifers Brachionus plicatilis. Before transfer to experimental containers, halibut larvae were reared in a 288 l, $1.2 \mathrm{~m}$ diameter black tank and diamond turbot larvae were reared in $15 \mathrm{l}$ black tanks. Each experiment (Table 1) was conducted with eggs or larvae from the same spawn.

Experimental conditions. Five delayed feeding experiments were conducted (Table 1). Experiments were run with light cycles (10L:14D) that simulated natural conditions and at temperatures of approximately $16^{\circ} \mathrm{C}$ for halibut larvae and $17^{\circ} \mathrm{C}$ for diamond turbot.

In first-feeding halibut experiments, late-stage eggs were transferred into clear glass or plastic experimental containers (Table 1). These eggs hatch about $2 \mathrm{~d}$ after fertilization at $16^{\circ} \mathrm{C}$ (S. M. Caddell \& D. M. Gadomski unpubl.). For first-feeding diamond turbot trials, 2-d-old larvae with unpigmented eyes and undeveloped mouths were transferred. Rotifers were introduced into containers at various intervals before and after yolk depletion and replenished as needed to maintain densitjes of $15 \mathrm{ml}^{-1}$; in most cases, trials were replicated. One experiment was conducted on each species in which dead eggs and larvae were counted and removed daily. An additional experiment (Expt II) was conducted on halibut in which only final survival was observed in order to add a trial (Day 6, the day of yolk depletion) not conducted initially. Notochord lengths (tip of snout to notochord end) of surviving firstfeeding halibut were measured at the conclusion of the experiments.

Experimental 3-wk-old halibut and diamond turbot larvae had been fed to excess since hatching and had unflexed notochords or were in the process of flexion. They were transferred by beaker to black experimental containers (Table 1). Rotifers (15 to $20 \mathrm{ml}^{-1}$ ) were added after specific periods of food deprivation. Initial rotifer concentrations were maintained by daily replenishment. Dead larvae were counted and removed daily. Halibut trials were ended $6 \mathrm{~d}$ after all larvae in the unfed trial had died; turbot experimental duration was longer because 1 unfed individual survived $7 \mathrm{~d}$ beyond other unfed turbot. At the conclusion of the experiments, live lengths (snout tip to notochord tip until full notochord flexion, then to the posterior edge of the hypurals) of surviving halibut and diamond turbot were measured.

After measurement, diamond turbot were placed back into their experimental containers and maintained $38 \mathrm{~d}$ beyond the initial food deprivation experiment to continue monitoring growth and development. Each experimental container received equal amounts of brine shrimp (Artemia sp.) nauplii. After $38 \mathrm{~d}$, lengths and developmental stages of turbot were determined.

Data analysis. To distinguish between the effects of different starvation intervals on groups of larvae, survival curves were statistically compared using the Mantel-Haenszel test, also called the log-rank test (Matthews \& Farewell 1985). The log-rank method compares mortality data of 2 or more trials ( $n$ ) to address the null hypothesis that survival experiences were the same in all trials. The test statistic $(T)$ is the summation of $n$ chi-square-type quantities. Each of these quantities is a squared deviation of expected mortality from

Table 1. Experimental conditions. Lengths are of specimens preserved in 5\% tormalın. First-feeding lengths are of newly hatched larvae. Daily mortality observations were conducted on all experiments except Expt II

\begin{tabular}{|lllccc|}
\hline Stage & Experiment & $\begin{array}{c}\text { Species (age at ex- } \\
\text { perimental initiation) }\end{array}$ & $\begin{array}{c}\text { Mean larval length } \\
\text { (mm) }\end{array}$ & $\begin{array}{c}\text { No. individuals initial- } \\
\text { ly per container }\end{array}$ & Container size (I) \\
\hline First-feeding & I & Halibut & 1.5 & 75 & 3 \\
& II & Halibut & 1.5 & 75 & 3 \\
3 3-wk-old & III & Diamond turbot & 1.7 & 50 & 3 \\
& IV & Halibut & 5.4 & 30 & 9 \\
& (21d) & Diamond turbot & 4.4 & 30 & 9 \\
\hline
\end{tabular}


observed mortality divided by expected mortality. The expected mortality in a trial is calculated by assuming equal mortality in all trials at each observation time. The test statistic is evaluated as a chi-square random variable with $n-1$ degrees of freedom.

Survival curves from replicate $(n=2)$ containers were first compared to see if replicates could be combined in subsequent analyses. Of 18 paired replicate comparisons, 17 pairs were not significantly different (alpha $=0.05$ ). Data from replicate containers were therefore combined and all trials in an experiment were tested for equality using the log-rank test. If significance $(p<0.05)$ was found in this initial test, curves were visually examined and comparisons were conducted on subsets of curves to test specific hypotheses about effects of food deprivation on survival.

Mean larval lengths between trials were compared using analysis of variance (ANOVA) on natural logtransformed values. Duncan's multiple range test (alpha $=0.05$ ) was used to compare means if a significant difference was found with ANOVA.

Four specific factors that may have affected turbot growth during the $38 \mathrm{~d}$ grow-out period were investigated using stepwise multiple regression analysis. These factors were (1) starvation time in prior experi- ments, (2) larval length at the start ot the grow-out period, (3) developmental stage at this time (eye position), and (4) initial larval density per container.

\section{RESULTS}

\section{First-feeding larvae}

Yolk depletion of first-feeding halibut occurred $6 \mathrm{~d}$ after hatching. Eyes were fully pigmented and mouths appeared functional on the fourth day after hatching. Larval survival patterns were significantly different between trials ( $T=67.7, p<0.001, \mathrm{df}=4$; Fig. 1 A). The survival functions of larvae fed on Days 4 and 5 after hatching were not statistically different ( $T=3.6, p=$ 0.057 , df $=1$ ) but this low probability and the different end points ( 46.7 and $34.7 \%$ survival) of the curves suggest better survival for larvae that have food available sooner after hatching. Survival curves for unfed larvae and those fed on Days 7 and 8 were not statistically different $(T=5.7, p=0.058, \mathrm{df}=2)$. All larvae that died after food was added had empty guts, indicating that feeding was not initiated following a period of starvation.
Fig. 1. (A) Paralichthys californicus and (B) Hypsopsetta guttulata. Survival curves of firstfeeding (A) halibut and (B) diamond turbot. Feeding was delayed for various intervals after hatching; day food was added is indicated next to the appropriate curve. Points are means of replicates $(n=2)$. Arrows indicate day of total yolk depletion

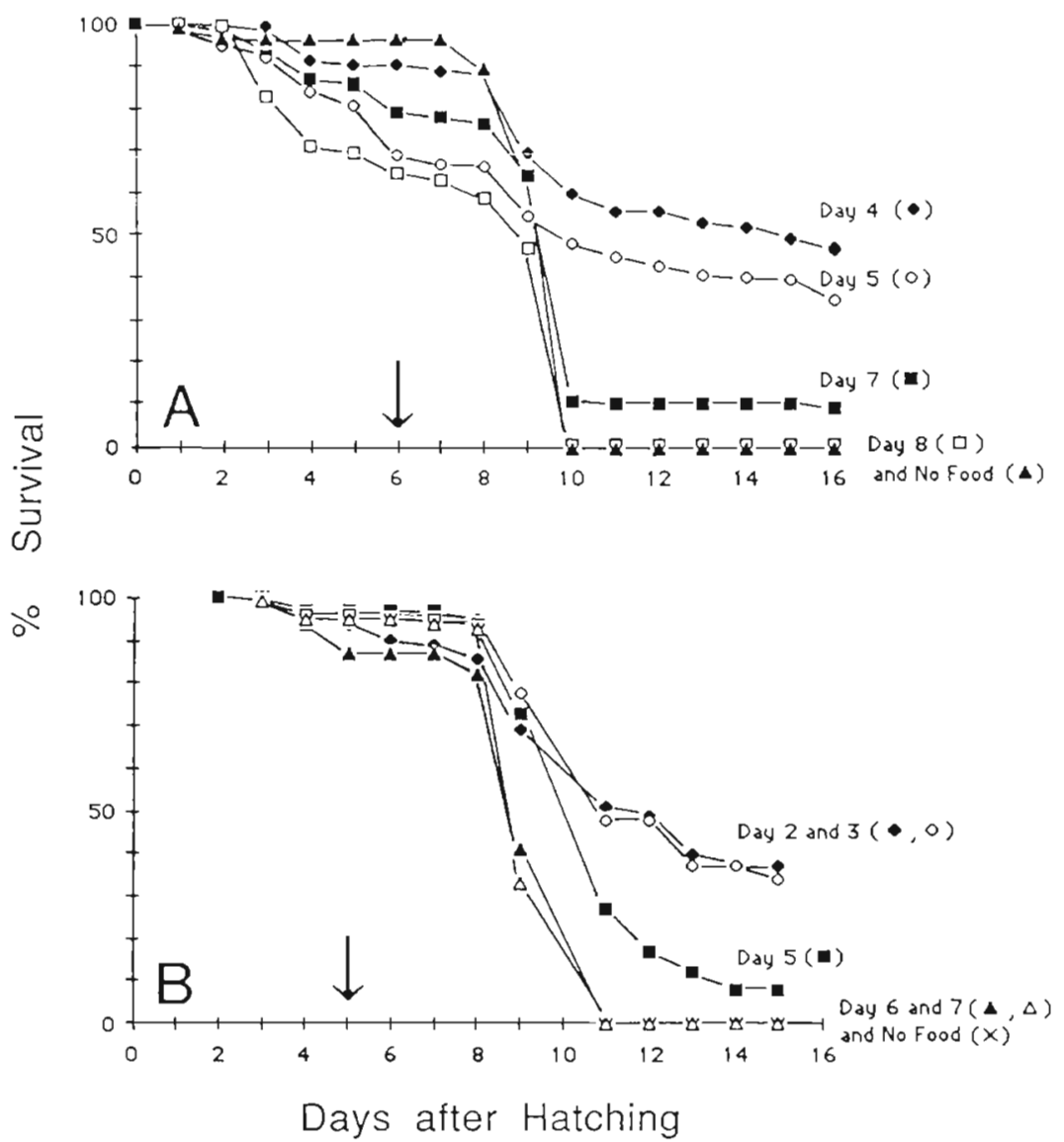


The conclusion that survival is significantly greater if food is added on or before yolk depletion was corroborated by the additional experiment (Expt II) conducted on first-feeding halibut larvae in which daily mortalities were not monitored; instead, number of larvae

Table 2. Paralichthys californicus. Mean percent survival $15 \mathrm{~d}$ after hatching of first-feeding halibut larvae initially fed various times after hatching (Day fed). No daily mortality observations were conducted (Expt II). N: number of replicate experimental containers per trial. Trials with the same superscript letter had mean percent survivals that did not significantly differ ( 1 -way ANOVA, alpha $=0.05$, arcsine-transformed percents). Yolk depletion occurred on Day 6

\begin{tabular}{|c|c|c|c|}
\hline Day fed & $N$ & $\begin{array}{c}\text { 6 Surviva } \\
\qquad \bar{x}\end{array}$ & $S D$ \\
\hline 4 & 2 & $21.3^{\mathrm{a}}$ & $(5.7)$ \\
\hline 5 & 1 & $21.3^{a}$ & \\
\hline 6 & 2 & $28.0^{a}$ & (11.3) \\
\hline 7 & 2 & $12.0^{\mathrm{ab}}$ & (11.3) \\
\hline 8 & 2 & $2.0^{\mathrm{b}}$ & $(1.0)$ \\
\hline No food & 2 & $0.0^{c}$ & $(0.0)$ \\
\hline
\end{tabular}

surviving on Day 15 were counted (Table 2). There was a significant difference in mean survival by day fed $(F=8.0, p=0.02, \mathrm{df}=5)$. Percent survivals of larvae initially fed 4,5 and $6 \mathrm{~d}$ after hatching did not significantly differ and were higher than for larvae first fed after yolk depletion.

The size of first-feeding halibut larvae also showed the effects of delayed feeding. Mean lengths of larvae fed on or before yolk depletion (Days 4 through 6) were from 6 to $17 \%$ greater than those first fed after yolk depletion (Days 7 and 8; Table 3). Size differences were largely due to the greater maximum length of larvae in groups fed earlier. Minimum length was not affected by timing of feeding, with one exception (Expt II. Day 7; Table 3).

Yolk depletion of diamond turbot larvae occurred $5 \mathrm{~d}$ after hatching. Eyes were fully pigmented $4 \mathrm{~d}$ after hatching and mouths also appeared functional at this time. The survivorship curves (Fig. 1B) of the 6 treatments (food first added 2,3,5,6 and $7 \mathrm{~d}$ after hatching. and larvae unfed) were significantly different ( $T=93.9$, $p<0.001, \mathrm{df}=5$ ). Best survival (about $35 \%$ on Day 15 ) occurred when larvae were fed before yolk depletion (Days 2 and 3); there was no difference in survivorship patterns between these 2 trials $(T=0.4, p=0.55, \mathrm{df}=$ 1). A smaller percentage ( $8 \%)$ survived if fed on the day of complete yolk depletion (Day 5), and all larvae fed after yolk depletion or never fed died by Day 11.

\section{Three-wk-old larvae}

Differing periods of food deprivation resulted in significant differences $(T=84.6, p<0.001, \mathrm{df}=4)$ in the survivorship patterns of 3 -wk-old halibut larvae (Fig. 2A). Final survival in control containers (fed throughout the $12 \mathrm{~d}$ experiment) was $73 \%$. Starvation for $1 \mathrm{~d}$ decreased survival to $64 \%$ on Day $12 ; 3$ and $4 \mathrm{~d}$ of food deprivation resulted in less than $25 \%$ survival. Highest mortalities occurred after the second day of the experiment. Unfed larvae all died by the sixth day. In contrast to first-feeding halibut larvae, many older larvae that died after being fed had full guts. Lengths of larvae that survived to the end of the experiment (Table 4) were not significantly related to the food deprivation periods $(F=2.4, p=0.07$, df $=3)$.

Table 3. Paralichthys californicus. Mean notochord lengths of first-feeding halibut larvae fed various times after hatching (Day fed). Experimental termination was 16 and $15 \mathrm{~d}$ after hatching for Expts I and II, respectively. In addition, mean lengths of the 5 smallest and 5 largest larvae in each trial are presented (except Expt II, Day 8, where $N=3$ ). In each column of each experiment, trials with the same superscript letter had mean lengths that did not significantly differ (1-way ANOVA, alpha = 0.05). Yolk depletion occurred on Day 6

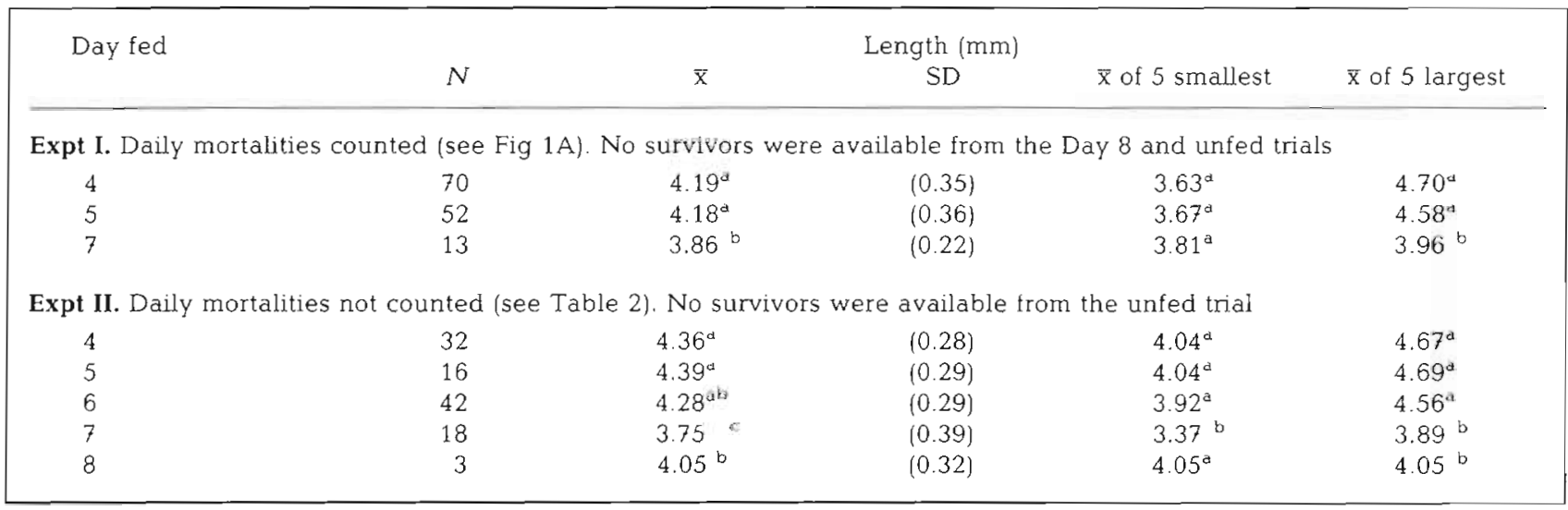


Fig. 2. (A) Paralichthys californicus and (B) Hypsopsetta guttulata. Survival curves of 3 -wk-old (A) halibut and $(B)$ diamond turbot. Length of food deprivation (day fed) is indicated next to the appropriate curve. Points are means of replicates $(n=2)$

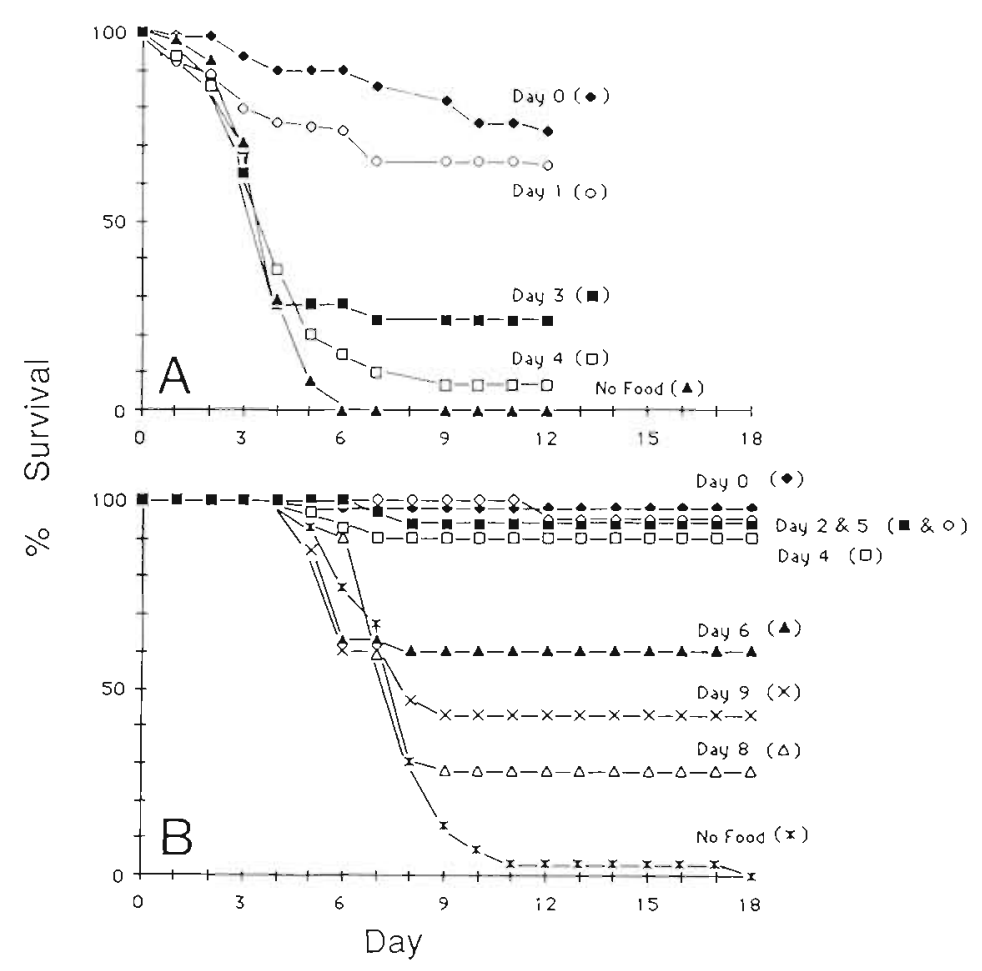

Table 4. Paralichthys californicus. Mean lengths on Day 12 of 3-wk-old halibut larvae deprived of food for various periods (Day fed). Means do not significantly differ (1-way ANOVA, alpha $=0.05$ )

\begin{tabular}{|cccc|}
\hline Day fed & \multicolumn{3}{c|}{ Length $(\mathrm{mm})$} \\
& $N$ & $\overline{\mathrm{x}}$ & $\mathrm{SD}$ \\
\hline 0 & 47 & 6.48 & $(0.36)$ \\
1 & 41 & 6.28 & $(0.51)$ \\
3 & 15 & 6.57 & $(0.40)$ \\
4 & 4 & 6.31 & $(0.50)$ \\
\hline
\end{tabular}

Three-wk-old diamond turbot larvae were very hardy in the laboratory, surviving well in the fed treatment and recovering quickly from periods of starvation (Fig. 2B). When food was provided throughout the experimental period or when larvae were starved for $5 \mathrm{~d}$ or less, final survivorship (on Day 18) was greater than $90 \%$ in most containers; survivorship curves were not significantly different for these treatments (Days 0 , 2,4 and $5 ; T=3.2, p=0.36, \mathrm{df}=3$ ). If larvae were starved for 6 or more days, mortality was high after the fifth day. When food was added after a period of starvation, almost all diamond turbot larvae began to feed and survived through the rest of the experiment.

Unlike 3-wk-old halibut larvae, growth of older diamond turbot larvae was inversely proportional to the period of starvation (Table 5). Larvae fed throughout the experiment averaged $7.2 \mathrm{~mm}$ on Day 18, while
Table 5. Hypsopsetta guttulata. Mean lengths on Day 18 of 3 wk-old diamond turbot larvae deprived of food for various periods (Day fed). Trials with the same superscript letter had mean lengths that did not significantly differ (1-way ANOVA, alpha $=0.05$ )

\begin{tabular}{|cccc|}
\hline Day fed & \multicolumn{3}{c|}{$\begin{array}{c}\text { Length }(\mathrm{mm}) \\
\overline{\mathrm{x}}\end{array}$} \\
& $N$ & $\mathrm{SD}$ \\
\hline 0 & 59 & $7.20^{\mathrm{a}}$ & $(0.48)$ \\
2 & 55 & $7.01^{\mathrm{a}}$ & $(0.45)$ \\
4 & 27 & $6.62^{\mathrm{b}}$ & $(0.47)$ \\
5 & 30 & $6.66^{\mathrm{b}}$ & $(0.61)$ \\
6 & 18 & $6.41^{\mathrm{b}}$ & $(0.63)$ \\
8 & 8 & $6.67^{\mathrm{b}}$ & $(0.70)$ \\
9 & 13 & $6.06^{\mathrm{c}}$ & $(0.43)$ \\
\hline
\end{tabular}

larvae starved for an increasing number of days were significantly smaller; $9 \mathrm{~d}$ of starvation caused survivors to be 6 to $16 \%$ shorter than all other larvae. Also, developmental rate was slowed by longer periods of food deprivation. Only $38 \%$ of the larvae in the $9 \mathrm{~d}$ starved trial had full notochord flexion, in contrast to over $95 \%$ full flexion in all other trials. All of the fed larvae had fully migrated eyes, whereas only $38 \%$ of the $9 \mathrm{~d}$ starved group exhibited this characteristic.

At the end of the second stage of the diamond turbot trials ( $38 \mathrm{~d}$ of grow-out), the 9 containers had from 4 to 28 (79-d-old) larvae whose mean length per container ranged from 11.4 to $14.4 \mathrm{~mm}$ (Fig. 3). All larvae were fully metamorphosed and settled. Larvae that had been 


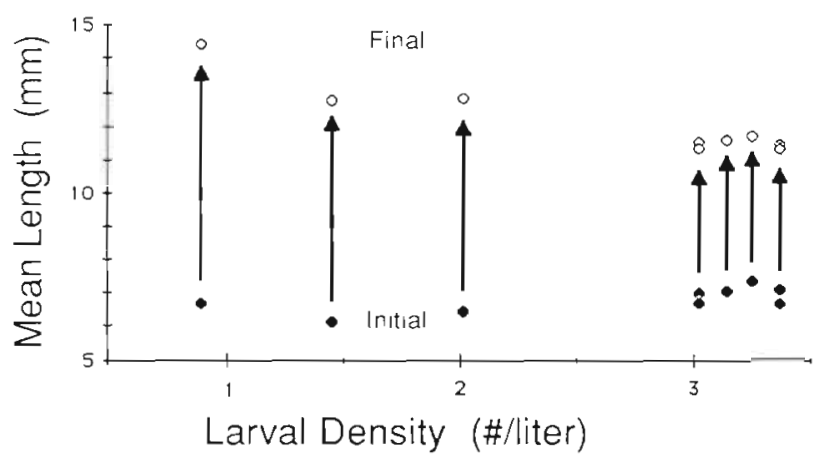

Fig. 3. Hypsopsetta guttulata. Change in diamond turbot mean length during the $38 \mathrm{~d}$ grow-out period as related to initial larval density in an experimental container Closed symbols: initial mean larval length; open symbols: final mean length

starved longest during the initial delayed feeding trials and consequently were the shortest at the beginning of the grow-out period were the largest at the end and thus showed the greatest percent increase. In the 3 containers with larvae that had been starved 6,8 and $9 \mathrm{~d}$, larval length doubled during the grow-out period (100, 116 and $110 \%$ change, respectively), whereas in the other 6 containers ( 0 to $5 \mathrm{~d}$ of starvation), average percent increase was only $65 \%$ (range 60 to $71 \%$ ). Larval density and initial larval length were the only significant variables affecting growth (Table 6), with initial density explaining over $90 \%$ of the variation in final larval length. Total mortality during the grow-out period was minimal (mean $4.4 \%$ ) in all but the $8 \mathrm{~d}$ starved container where 4 of 8 larvae died.

\section{DISCUSSION}

Although many unfed halibut and diamond turbot larvae in our study were alive and active until about $3 \mathrm{~d}$ after yolk depletion, larvae of both species required food on or before yolk depletion for best survival. This requirement is similar to other species with small pelagic eggs (about $1 \mathrm{~mm}$ diameter) and yolk-sac larvae ( 1.5 to $3 \mathrm{~mm}$ in length) (Lasker et al. 1970, Houde 1974, Hunter \& Kimbrell 1980, Bagarinao 1986). Larger larvae and those with more yolk, such as herring Clupea harengus (Blaxter \& Hempel 1963), Japanese sand eel Ammodytes personatus (Yamashita \& Aoyama 1986) and grunion Leuresthes tenuis (May 1971), are more resistant to starvation because of their greater nutritional reserves. Grunion and sand eel are unusual in that they did not reach a 'point-of-no-return (PNR)'; no matter how long food was withheld, the majority of surviving larvae were able to successfully feed.

The mean length of first-feeding halibut was significantly less if feeding was delayed until after yolk absorption. Similar results have been reported for larval red drum Sciaenops ocellata (Roberts et al. 1978). Depressed larval growth rate could result in greater mortality, since smaller larvae are at a disadvantage in searching out food (Blaxter \& Staines 1971, Hunter 1972) and avoiding predators (Lillelund \& Lasker 1971, Bailey 1984, Bailey \& Batty 1984, Folkvord \& Hunter 1986). The length of starvation did not affect minimum size of halibut, however. This suggests that halibut larvae have a minimum necessary growth rate for survival, a pattern that has been reported for larvae of other species (Jones 1973, Beyer \& Laurence 1980, Govoni et al, 1986).

Food deprivation studies on older larvae are not as common as those on yolk-sac larvae, and there is more interspecific variability in resistance to starvation. Less active species, such as flatfishes, are more resistant to starvation, particularly after metamorphosis (Yin \& Blaxter 1987). Blaxter \& Ehrlich (1974) found that plaice Pleuronectes platessa at the beginning of metamorphosis (about $10 \mathrm{~mm}$ ) reached the PNR after $23 \mathrm{~d}$ of starvation. In the same study, $30 \mathrm{~d}$ old herring Clupea harengus reached this point after $8 \mathrm{~d}$ of starvation, and when $88 \mathrm{~d}$ old, could resist $15 \mathrm{~d}$ of food deprivation. Anchovy larvae Engraulis mordax about $35 \mathrm{~mm}$ and

Table 6. Hypsopsetta guttulata. Regression model of diamond turbot final length in the $38 \mathrm{~d}$ grow-out experiment. Stepwise multiple regression was used with probabilities for individual variables to enter or leave set at 0.15 . Starvation time and eye position were included as independent variables but did not enter the model

\begin{tabular}{|c|c|c|c|c|c|c|}
\hline Source & Df & Sum-squares & Mean squares & F-value & Prob $>F$ & $R^{2}$ \\
\hline Model & 2 & 8.51 & 4.25 & 81.49 & 0.000 & 96.45 \\
\hline Error & 6 & 0.31 & 0.05 & & & \\
\hline Total & 8 & 8.82 & & & & \\
\hline Parameter & & $B$-estimate & $\mathrm{SE}$ & Type II SS & $F$-value & Prob $>F$ \\
\hline Intercept & & 9.71 & & & & \\
\hline Initial density & & -0.15 & 0.01 & 6.74 & 129.01 & 0.000 \\
\hline Initial length & & 0.86 & 0.28 & 0.51 & 9.68 & 0.021 \\
\hline
\end{tabular}


beginning metamorphosis reached the PNR after $15 \mathrm{~d}$ of starvation (Hunter 1976a). First-feeding larvae of Pacific mackerel Scomber japonicus required food within a day after yolk absorption (Hunter \& Kimbrell 1980); however, newly metamorphosed mackerel could only resist a few more days of starvation due to their high growth rate and activity level (common characteristics of scombroid larvae).

Three-wk-old diamond turbot survived much longer periods of starvation than did halibut, although mortality of both species was proportional to days of food deprivation. Also, older diamond turbot larvae did not exhibit a PNR as did older halibut larvae. Premetamorphosed turbot would typically lie on the bottom after about a week of starvation, but when presented with food most swam up to begin eating and consequently survived. Conversely, starved 3-wk-old halibut larvae that exhibited inactivity did not initiate feeding when food was offered. Many active starved halibut that died after being fed had food in their guts, however, indicating that they had responded to prey. Perhaps this phenomenon was due to an inability to digest food, since one of the first structures to deteriorate during starvation is the digestive tract (Kostomarova 1962, Theilacker 1978, Watanabe 1985, Yin \& Blaxter 1986) with a possible decline in proteolytic enzyme activity (Dabrowski 1982).

Starvation-induced morphological differences have been reported for larvae of fish species such as plaice Pleuronectes platessa (Shelbourne 1957. Wyatt 1972), grunion Leuresthes tenuis (May 1971), herring Clupea harengus (Ehrlich et al. 1976), cod Gadus morhua and flounder Platichthys flesus (Yin \& Blaxter 1986). Threewk-old diamond turbot subjected to longer periods of food deprivation were smaller and less developed than fed individuals - fed turbot were benthic and fully metamorphosed, while many starved larvae were still in the water column and only beginning to metamorphose. Conversely, starved 3-wk-old halibut did not differ in morphology, probably because the intervals of food deprivation endured were shorter than those endured by turbot. In the field, pelagic larvae may be at a competitive disadvantage to settled larvae because they are more visible to predators and utilize more energy due to their higher activity level. A period of starvation would thus be detrimental in prolonging this vulnerable stage and might result in higher mortalities.

Growth of diamond turbot was monitored for an additional $38 \mathrm{~d}$ following the initial food deprivation experiment to determine if smaller, less developed larvae could recover. Recovery growth of larval whitefish Coregonus lavaretus and peled Coregonus peled after intervals of fasting has been reported, although this improved growth rate might be due to selective survival of only the most robust individuals (Dabrowski et al. $1986 a$, b). During the grow-out period, smaller diamond turbot larvae grew at a faster rate than those larvae that were initially larger. Larval density explained most of the observed variation in final larval size, although interpretation of these results is complicated by interrelated factors. Containers initially with smaller larvae were also those with lower larval densities (both as a result of longer starvation periods) and food was not present in excess at all times (although each container received the same quantity). Possibly, because of the food-limiting situation, larvae in the lower density containers had more to eat allowing them to grow faster.

Survival of fish larvae in the nearshore zone of California could be related to the seasonal pattern of zooplankton prey abundance. Halibut larvae occur in this area ( 1 to $20 \mathrm{~km}$ offshore) throughout the year but abundance maxima are consistently observed in late winter through spring (Lavenberg et al. 1986). Petersen et al. (1986) found that zooplankton biomass in the nearshore zone increases in the spring with maximum biomass usually observed in late spring or early summer. Thus, halibut larvae are often present during seasonal periods of maximum zooplankton abundance and relatively high regional food levels. In contrast, diamond turbot spawn most intensely during late fall and early winter (Natural History Museum of Los Angeles County unpubl.), a period characterized by low zooplankton biomass. Not enough information is presently available on spawning range, feeding conditions (such as small-scale zooplankton patchiness; Owen 1981, Haury \& Wiebe 1982j and other factors to understand diamond turbot spawning strategy. For high survival of newly hatched turbot, however, spawning must be near or within reasonably productive patches of water, since first-feeding larvae have been shown to be sensitive to short periods of food deprivation.

Older diamond turbot are much more resistant to periods of starvation than older halibut. This adaptation may be in response to the relatively low zooplankton densities or greater interpatch distances that turbot larvae might encounter in fall and winter. Survival under different regimes of prey availability is speciesspecific. Houde \& Schekter (1978) found that survival $(59.3 \%)$ of newly hatched sea bream Archosargus rhomboidalis larvae on high densities of food for $6 \mathrm{~h}$ a day was comparable to survival (42.0\%) with constant food, and $22.0 \%$ survived patch exposure times as low as $1.5 \mathrm{~h} \mathrm{~d}^{-1}$. In contrast, newly hatched bay anchovy Anchoa mitchilli required constant food for best survival $(22.9 \%)$; only a small percentage of larvae survived shorter exposure times. Additional work must be conducted on larval response to variable feeding regimes in order to more fully understand the effects of patchi- 
ness on growth and survival. It is also important that complementary research be conducted in the field to determine the temporal and spatial distributions of prey patches that larvae might encounter.

Acknowledgements. Special thanks to S. Caddell for assisting in the experiments and for his many helpful comments. K. Fujimoto, G. Caddell and T Caro also provided valuable laboratory assistance. Thanks to C. Murray for statistical advice, and to A. Jahn, G. Boehlert, R. Lavenberg, J. Stephens and 2 anonymous readers for reviewing the manuscript. Financial support has been provided by the California Department of Fish and Game and the Southern California Edison Company.

\section{LITERATURE CITED}

Bagarinao, T. (1986). Yolk resorption, onset of feeding and survival potential of larvae of three tropical marine fish species reared in the hatchery. Mar. Biol. 91 449-459

Bailey, K. M. (1984). Comparison of laboratory rates of predation on five species of marine fish larvae by three planktonic invertebrates: effects of larval size on vulnerability. Mar. Biol. 79: 303-309

Bailey, K. M., Batty, R. S. (1984). Laboratory study of predation by Aurelia aurita on larvae of cod, flounder, plaice and herring: development and vulnerability to capture. Mar. Biol. 83: 287-291

Beyer, J. E., Laurence, G. C. (1980). A stochastic model of larval fish growth. Ecol. Model. 8: 109-132

Blaxter, J. H. S., Ehrlich., K. F. (1974). Changes in behavior during starvation of herring and plaice larvae. In: Blaxter J. H. S. (ed.) The early life history of fish. Springer-Verlag, New York, p. 575-588

Blaxter, J. H. S., Hempel, G. (1963). The influence of egg size on herring larvae (Clupea harengus L.). J. Cons. int. Explor. Mer 28: 211-244

Blaxter, J. H. S., Staines, M. E. (1971). Food searching potential in marine fish larvae. In: Crisp, D. J. (ed.) Proceedings 4th European Marine Biology Symposium. Cambridge University Press, Cambridge, p. 467-485

Buckley, L. J. (1982). Effects of temperature on growth and biochemical composition of larval winter flounder Pseudopleuronectes americanus. Mar Ecol. Prog. Ser. 8: 181-186

Cushing, D. H. (1975). Marine ecology and fisheries. Cambridge University Press, New York

Dabrowski, K. (1982). Proteolytic enzyme activity decline in starving fish alevins and larvae. Environ. Biol. Fish. 7: $73-76$

Dabrowski, K., Takashima, F., Strussmann. C. (1986a). Does recovery growth occurs in larval fish? Bull. Jap. Soc. scient. Fish. 52: 1869

Dabrowski, K., Takashima, F., Strussmann, C., Yamazaki, T (1986b). Rearing of coregonid larvae with live and artificial diets. Bull. Jap. Soc. scient. Fish. 52: 213-30

Ehrlich, K. F., Blaxter, J. H. S., Pemberton, R. (1976). Morphological and histological changes during the growth and starvation of herring and plaice larvae. Mar. Biol. 35: $105-118$

Folkvord, A., Hunter, J. R. (1986). Size-specific vulnerability of northern anchovy, Engraulis mordax, larvae to predation by fishes. Fish. Bull. U. S. 84: 859-869

Govoni, J. J., Boehlert, G. W., Watanabe, Y (1986). The physiology of digestion in fish larvae. Environ. Biol. Fish. 16: $59-77$
Haury, L.R., Wiebe, P. H. (1982). Fine-scale multi-species aggregation of oceanic zooplankton. Deep Sea. Res. 29 (7A): 915-921

Houde, E. D. (1974). Effects of temperature and delayed feeding on growth and survival of larvae of three species of subtropical marine fishes. Mar. Biol. 26: 271-285

Houde, E. D., Schekter, R. C. (1978). Simulated food patches and survival of larval bay anchovy, Anchoa mitchilli, and seabream, Archosargus rhomboidalis. Fish. Bull. U. S. 76 : $483-487$

Houde, E. D., Schekter, R. C. (1981). Growth rates, rations and cohort consumption of marine fish larvae in relation to prey concentrations. Rapp. P.-v. Rêun. Cons. int. Explor. Mer 178: 441-453

Hunter, J. R. (1972). Swimming and feeding behavior of larval anchovy Engraulis mordax. Fish. Bull. U. S. 70: 821-838

Hunter, J. R. (1976a). Culture and growth of northern anchovy, Engraulis mordax, larvae. Fish. Bull. U.S. 74 : $81-88$

Hunter, J. R. (ed.) (1976b). Report of a colloquium on larval fish mortality studies and their relation of fishery research, Jan 1975. NOAA Tech. Rep. NMFS Cir-395: 1-5

Hunter, J. R., Krimbrell, C. A. (1980). Early life history of Pacific mackerel, Scomber japonicus. Fish. Bull. U. S. 78: 89-101

Jones, R. (1973). Density dependent regulation of the numbers of cod and haddock. Rapp. R.-v. Réun. Cons. int. Explor. Mer 164: 156-173

Kostomarova, A. A. (1962). Effect of starvation on the development of the larvae of bony fishes. Tr. Inst. Morfol. Zhivotn Akad. Nauk. USSR 40: 4-77

Lasker, R., Feder, H. M., Theilacker, G. H., May, R. C. (1970). Feeding, growth and survival of Engraulis mordax larvae reared in the laboratory. Mar. Biol. 5: 345-353

Lavenberg, R. J., McGowen, G. E., Jahn, A. E., Petersen, J. H., Sciarrotta, T. C. (1986). Abundance of southern California nearshore ichthyoplankton: 1978-1984. CalCOFI Rep. 27 : $53-64$

Lillelund, K., Lasker, R. (1971). Laboratory studies of predation by marine copepods on fish larvae. Fish. Bull. U. S. 69 : 655-667

Matthews, D. E, Farewell, V T (1985). Using and understanding medical statistics. Karger, New York

May, R. C. (1971). Effects of delayed feeding on larvae of the grunion, Leuresthes tenuis, (Ayres). Fish. Bull. U. S. 69: $411-425$

May, R. C. (1974). Larval mortality in marine fishes and the critical period concept. In: Blaxter, J. H. S. (ed.) The early life history of fish. Springer-Verlag, New York. p. 3-19

McGurk, M. D. (1984). Effects of delayed feeding and temperature on the age of irreversible starvation and the rates of growth and mortality of Pacific herring larvae. Mar. Biol. 84: $13-26$

O Connell, C. P. (1976). Histological criteria for diagnosing the starving condition in early post yolk sac larvae of the northern anchovy, Engraulis mordax Girard. J. exp. mar Biol. Ecol. 25: 285-312

Owen, R. W (1981). Microscale plankton patchiness in the larval anchovy environment. Repp. R.-v. Réun. Cons. int. Explor. Mer 178: 364-368

Petersen, J. H., Jahn, A. E., Lavenberg, R. J., McGowen, G. E., Grove, R. S. (1986). Physical-chemical characteristics and zooplankton biomass on the continental shelf off southern California. CalCOFI Rep. 27: 36-52

Roberts, D. E., Morey III, L. A., Henderson, G. E., Halscott, K. R. (1978). The effects of delayed feeding, stocking density and food density on the survival, growth and 
production of larval red drum (Sciaenops ocellata). In: Avault, J. W., Jr (ed.) Proc. 9th Ann. Meet. World Maric. Soc. Louisiana State Univ., Division of Continuing Education, p. 333-343

Shelbourne, J. E. (1957). The feeding and condition of plaice larvae in good and bad plankton patches. J. mar. biol. Ass. U. K. 36: 539-552

Sherman, K., Smith, W., Morse, W., Berman, M., Green, J., Ejsymont, L. (1984). Spawning strategies of fishes in relation to circulation, phytoplankton production, and pulses in zooplankton off the northeastern United States. Mar. Ecol. Prog. Ser 18: 1-19

Theilacker, G. H. (1978). Effect of starvation on the histological and morphological characteristics of jack mackerel, Trachurus symmetricus, larvae. Fish. Bull. U. S. 76 : 403-414

Townsend, D. W. (1983). The relations between larval fishes and zooplankton in two inshore areas of the Gulf of Maine. J. Plankton Res. 5: 145-173

Watanabe, Y. (1985). Histological changes in the liver and intestine of freshwater goby larvae during short-term starvation. Bull. Jap. Soc. scient. Fish. 51 707-709

Wyatt, $T$ (1972). Some effects of food density on the growth and behavior of plaice larvae. Mar. Biol. 14: 210-216

Yamashita, Y., Aoyama, T (1986). Starvation resistance of larvae of the Japanese sand eel Ammodytes personatus. Bull. Jap. Soc. scient. Fish. 52: 635-639

Yin, M. C., Blaxter, J. H. S. (1986). Morphological changes during growth and starvation of larval cod (Gadus morhua L.) and flounder (Platichthys flesus L.). J. exp. mar Biol. Ecol. 104: 215-228

Yin, M. C., Blaxter, J. H. S. (1987). Feeding ability and survival during starvation of marine fish larvae reared in the laboratory. J. exp. mar. Biol. Ecol. 105: 73-83

This article was presented by Dr R. Lasker; it was accepted for printing on February 5, 1988 